\title{
A NEW TECHNIQUE FOR INTRODUCING IUDS INTO RAT UTERI
}

\author{
T. RANDALL WRENN, JOAN R. WOOD AND JOEL BITMAN \\ U.S. Department of Agriculture, Animal Husbandry Research Division, \\ Agricultural Research Center, Beltsville, Maryland 20705, U.S.A.
}

(Received 8th April 1968)

\begin{abstract}
Summary. Intra-uterine contraceptive devices (IUDs) were made from monofilament nylon and inserted by a non-surgical technique through the cervical os of rats so as to be wholly within the uterine lumen. Most of these devices were retained and exhibited local contraceptive action in the uterine horn in which they were placed. This new method of insertion in rats offers advantages over other ways of studying the physiological and biochemical factors important to IUD function.
\end{abstract}

Increasing acceptance of the intra-uterine contraceptive device (IUD) as a method of population control makes necessary a better understanding of the mechanism(s) of action of such devices. More familiarity with the precise contraceptive nature of IUDs will probably lead to increased use and improved effectiveness of these methods.

The small size and low cost of the albino rat affords an opportunity for extensive laboratory investigations on the mechanism of IUD action. Further, the bicornate uterus of rats has proved to be especially advantageous since it offers the possibility of using the horn contralateral to the one containing the IUD as a control. Thus, although the control horn is independent and implantation and pregnancy can occur normally, it is under the same general hormonal, genetic, nutritional and metabolic influences as the IUD horn in which blastocysts do not implant. Differences of any kind that can be demonstrated to exist between the horns are possible causes of the infertility induced by IUDs.

A review of the literature on IUDs in rats and mice did not indicate that any investigators had inserted the devices through the cervix. All have been put in after laparotomy by sewing through the uterus, usually in two places (Doyle \& Margolis, 1963, 1964, 1966; Kar, Kamboj \& Datta, 1964; Kar, Goswami, Kamboj \& Chowdhury, 1964; Marston \& Chang, 1964; Schuchner \& Davidson, 1964; Chaudhury \& Tarak, 1965; Greenwald, 1965; Parr, 1966; Speilberger \& Olewine, 1966; Havránek, Dyková \& Tichý, 1967; Laumas \& Farooq, 1967).

Since insertion through the cervix seemed to offer advantages over the traumatic method being used, and further, since the cervical approach was more closely analogous to the practice in man, we investigated the efficacy of producing unilateral sterility by insertion of a device wholly within the uterine lumen. 
The nylon device used was made from $0.28 \mathrm{~mm}$ diameter, $8 \mathrm{lb}$ test, monofilament fishing leader stock purchased at a sporting goods store. It is rather similar in general configuration to the Lippes loop used in man, being a double $\mathrm{S}$ shape formed by winding the nylon leader material in figure 8 fashion over two very small headless wire nails spaced $2 \mathrm{~mm}$ apart. A wooden stick containing the nails and wound nylon was immersed in boiling water for 1 to $2 \mathrm{~min}$, and then cooled. Double S-shaped segments were then cut from the filament. These were in a single plane and resulted in a final device 6 to $7 \mathrm{~mm}$ long by $3 \mathrm{~mm}$ wide, possessing sufficient 'memory' to regain their shape after having been straightened when loaded into the inserter for introduction into the uterus.

Virgin female Wistar rats, 90 to 100 days old, were used. They were anaesthetized lightly with ether and their cervices viewed through an operating otoscope using a 5-mm aural speculum placed deep into the vagina. The cervix

TABLE 1

EFFECTS OF IUDS ON REPRODUCTIVE PERFORMANCE OF RATS

\begin{tabular}{|c|c|c|c|c|c|c|}
\hline & No. & $\begin{array}{c}\text { Horn } \\
\text { designation }\end{array}$ & $\begin{array}{l}\text { IUDs } \\
\text { found }\end{array}$ & $\begin{array}{c}\text { Embryos } \\
\text { /horn } \\
\text { (mean) }\end{array}$ & $\begin{array}{l}\text { Implantation } \\
\text { sites/horn } \\
\text { (mean) }\end{array}$ & $\begin{array}{l}\text { Corpora } \\
\text { lutea } \\
\text { (mean of } \\
24 \text { rats) }\end{array}$ \\
\hline $\begin{array}{l}\text { Unilaterally } \\
\text { pregnant rats }\end{array}$ & 34 & $\begin{array}{l}\text { Pregnant } \\
\text { IUD }\end{array}$ & $\begin{array}{r}0 \\
29\end{array}$ & $\begin{array}{r}5 \cdot 5 \\
0\end{array}$ & $\begin{array}{r}5 \cdot 8 \\
0\end{array}$ & $\begin{array}{l}7 \cdot 0 \\
7 \cdot 2\end{array}$ \\
\hline $\begin{array}{l}\text { Both horns } \\
\text { pregnant }\end{array}$ & 7 & Pregnant & $3^{*}$ & $4 \cdot 2$ & - & - \\
\hline Total & 41 & & 32 & & & \\
\hline
\end{tabular}

* Two found in the uterus, one in the vagina.

was cleaned of cellular debris with a cotton swab saturated with a $1: 1250$ aqueous solution of benzalkonium chloride. The equipment used in placing the IUDs is shown in Pl. 1, Fig. 1. Working through the speculum of the otoscope, an inserter, consisting of a 4-in. thin-wall 20-gauge hypodermic needle with blunted end, was carefully passed through either of the cervical canals and into the uterine horn for a total distance of 32 to $35 \mathrm{~mm}$. A picture of the cervix photographed through the otoscope is shown in Pl. 1, Fig. 2. The contraceptive device was expelled into the uterus by pushing on the stylet plunger. All instruments and the IUDs were stored in benzalkonium chloride solution before use. The rats were mated after the IUDs had been in place for at least 4 weeks and were killed between Days 10 and 21 of pregnancy.

The effects of the IUDs on pregnancy and corpora lutea formation are shown in Table 1. Comparison of the number of rats that were pregnant in only one horn (thirty-four) with the total rats in which IUDs were inserted (forty-one) reveals that the method was $83 \%$ effective in preventing pregnancy. The success of the procedure as measured by the number of IUDs recovered was $78 \%$, but it should be emphasized that this includes the first of the animals treated in this manner. Our technique of insertion improved as we gained experience, with the 


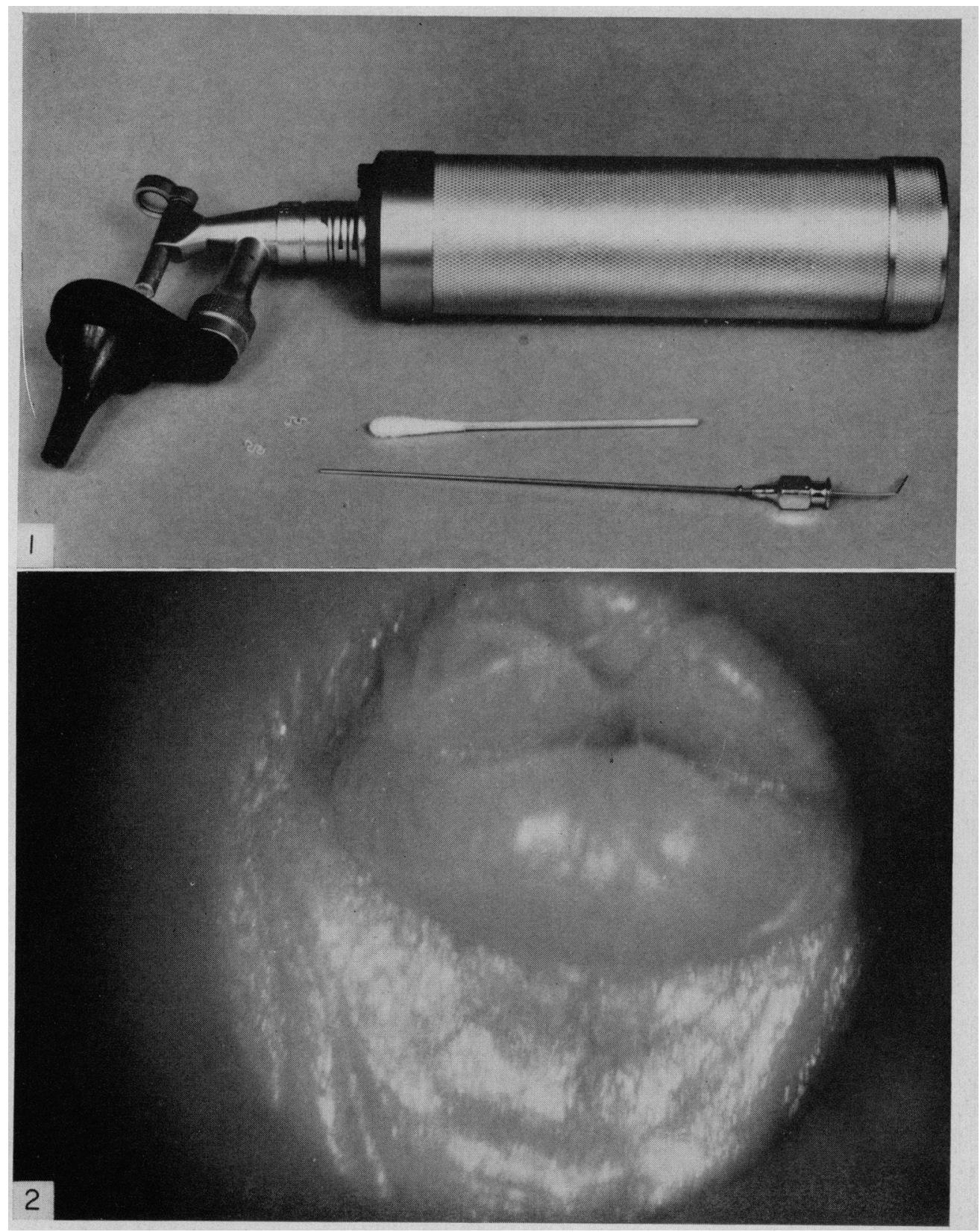

For, 1. Equipment used in inserting ILI)s in rats. Otosepe with 5 mm aumal speculam, cotton swab, inserter made of a 20 -gaduge hypedermic medle and It l)s ane shown. The ILI)s have been painted to increase the re risibility.

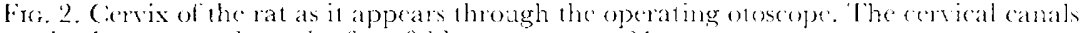
are in the centre where the four folds comerge. '24.

Facing 1.516, 
result that more IUDs were released at mid-horn than in the initial experiments. In a group of 110 rats in which IUDs were fitted subsequent to this first experiment, we have recovered 101 devices for a retention effectiveness of $92 \%$. It should be pointed out that failure to find an IUD does not necessarily mean that it was not in the uterus. Most of the IUDs were found in the lower two-thirds of the uterine horn, but occasionally they were located in the ovarian end or partially into the cervix. Visible accumulation of fluid in the IUD horn occurred in $54 \%$ of these pregnant rats. It ranged in consistency from a cloudy watery fluid to a thick greenish-yellow viscous paste. The contraceptive action of the IUD did not seem to depend on, or be related to, this fluid.

There are several favourable aspects of the IUD-insertion technique presented here, as compared with the methods used by others in investigating contraceptive devices in rats. The ease and rapidity of insertion, the avoidance of trauma associated with laparotomy and elimination of the complication of piercing the uterine wall are all advantages of the procedure. In addition, the IUD lies totally within the uterus, obviating the necessity of suture material inside the abdominal cavity and through the uterine muscle layers. Insertion can be accomplished at any time during the cycle or following mating. A further interesting and useful aspect is that it is very closely analogous to the methods used in women, both as regards the materials used and the manner of insertion.

It is believed that the method of IUD insertion presented here using a nylon double $\mathrm{S}$ device applied through the cervical os provides a superior method for the study of physiological and biochemical factors involved in intra-uterine contraception in the rat.

\section{REFERENCES}

Chaudhury, R. R. \& TARak, T. K. (1965) Effect of intrauterine silk thread suture on fertility of female rats. Br. med. . i, 31 .

Doyle, L. L. \& MARGolis, A. J. (1963) Intrauterine foreign body: Effect on pregnancy in the rat. Science, N.Y. 139, 833.

Doyle, L. L. \& MARGOLIs, A. J. (1964) Intrauterine foreign body. I. Effect on reproductive processes in the rat. Fert. Steril. 15, 597.

Doyle, L. L. \& Margolis, A. J. (1966) The effect of an IUFB on reproduction in mice. 7. Reprod. Fert. $11,27$.

GreEnwald, G. S. (1965) Interruption of pregnancy in the rat by a uterine suture. F. Reprod. Fert. 9, 9.

Havránek, F., Dyková, H. \& TíhÝ, M. (1967) The effect of an intra-uterine suture on fertility in the rat. F. Reprod. Fert. 14, 15.

Kar, A. B., Goswami, A., KamboJ, V. P. \& Chowdhury, S. R. (1964) Effect of a foreign body on the response of the uterus of ovariectomized rats to estrogen. Steroids, $4,159$.

Kar, A. B., Kamboj, V. P. \& DATTA, J. K. (1964) Effect of an intrauterine foreign body on the response of rat ovary to exogenous gonadotropin. Indian 7. exp. Biol. 2, 117.

LaUmas, K. R. \& FarooQ, A. (1967) Uptake and disappearance of $1,2 \cdot{ }^{3} \mathrm{H}$-progesterone from rat uterus in presence of intrauterine contraceptive. Indian F. exp. Biol. 5, 12.

Marston, J. H. \& Chang, M. C. (1964) Action of intra-uterine foreign bodies in the rat and rabbit. Proc. 2nd int. Conf. on Intra-uterine Contraception, New York, p. 243.

PARR, E. (1966) Glycogen accumulation in the rat uterus containing an intrauterine contraceptive device. Fert. Steril. 17, 797.

Schuchner, E. B. \& Davidson, O. W. (1964) Effect on rat pregnancy of an intrauterine silk thread. Proc. 2nd int. Conf. on Intra-uterine Contraception, New York, p. 248.

Speilberger, A. E. L. \& Olewine, D. A. (1966) The effect of an intra-uterine suture on pregnancy and deciduomata formation in the rat. Int. F. Fert. $11,15$. 